\title{
Biomarker response of ocean acidification induced hypercapnia on marine bivalve donax cuneatus, linnaeus 1758
}

\begin{abstract}
The present study reports the investigation of the sub lethal impacts of ocean acidification induced hypercapnia ( $\mathrm{pH} 7.5$ and 7.0) and leakage of sub sea bed Carbon Dioxide storage sites ( $\mathrm{pH}$ 6.5-5.5) on marine bivalve Donax cuneatus, Linnaeus 1758 collected from the Gulf of Mannar province. Fifteen days experiment was carried out in laboratory microcosms in a closely monitored environment. The impacts of Hypercapnia on Biomarker enzymes indicating neurotoxicity (Acetylcholinesterase), oxidative stress (lipid peroxidation and catalase) and phase II biotransformation of xenobiotics (glutathione S transferase, and reduced glutathione) were estimated. The increase in lipid peroxidation and catalase activities suggest hypercapnia induced oxidative stress. The decreasing $\mathrm{pH}$ also increased the activity of reduced glutathione and glutathione $\mathrm{S}$ transferase which acts as detoxifying enzymes for Hypercapnia induced toxicity however the hypercapnic conditions inhibited the levels of acetylcholine esterase which indicates the polluted environment substantiating stress induced high rate of mortality at low $\mathrm{pH}$ levels. The above used biomarkers thus provide a valuable tool for monitoring ocean acidification induced hypercapnic stress at a sublethal level.
\end{abstract}

Keywords: Ocean acidification, Hypercapnia, Microcosm, Donax cuneatus, Biomarkers
Volume 4 Issue 2 - 2016

\author{
Anand Muthusamy, Jeeva Priya R, \\ Maruthupandy M, Hameedha Beevi A \\ Department of Marine and Coastal Studies, Madurai Kamaraj \\ University, India \\ Correspondence: Anand Muthusamy, Department of Marine \\ and Coastal Studies, Madurai Kamaraj University, Madurai- 625 \\ 021, Tamilnadu, India, Tel +919-444-120-690, \\ Email anandm21@yahoo.com
}

Received: October 23, 2015 | Published: March 31, 2016
Abbreviations: AchE, Acetylcholine Esterase; ACTI, Acetylcholine Iodide; ANOVA, Analysis of Variance; BSA, Bovine Serum Albumin; CAT, Catalase; CDNB, Chlorodinitrobenzene; $\mathrm{CO}_{2}$, Carbon Dioxide; DO, Dissolved Oxygen; DOE, Department of Energy; DTNB, 5,5 Dithiobis - (2 Nitrobenzoic Acid); $\mathrm{fCO}_{2}$, Fugacity of Carbon Dioxide; GSH, Glutathione; GST, Glutathione - S - Transferase; $\mathrm{H}_{2} \mathrm{O}_{2}$, Hydrogen Peroxide; ICES, International Council for the Exploration of the Sea; IPCC, Intergovernmental Panel on Climate Change; MDA, Malonedialdehyde; OA, Ocean Acidification; $\mathrm{pCO}_{2}$, Partial Pressure of Carbon Dioxide; $\mathrm{pH}(\mathrm{T})$, Total Hydrogen Scale $\mathrm{pH}$; $\mathrm{R}^{2}$, Regression Value; SD, Standard Deviation; SDS, Sodium Dodecyl Sulphate; SRES, Special Report on Emission Scenario; TA, Total Alkalinity; TBA, Thiobarbituric Acid; TCA, Trichloroacetic Acid; UV Vis, Ultra Violet - Visible; $\varepsilon$, Molar Extinction Co Efficient

\section{Introduction}

Among the various stressors that coerce the marine environment ocean acidification plays a crucial role. Assessing the effects of such acidity on the chemistry and biology of the marine environment is substantial to interpret the

global changes over decades. $\mathrm{pH}$, the basic unit of acidity in seawater has already dropped by 0.1 units which accounts to $26 \%$ increase in acidity.$^{1,2}$ a further 0.3 to 0.4 units fall in $\mathrm{pH}$ is anticipated by $2100 .{ }^{3}$ Many measures have so far been established to moderate the emission of $\mathrm{CO}_{2}$ thereby restraining the negative impacts of $\mathrm{OA}$. Geologic $\mathrm{CO}_{2}$ sequestration is one such amelioration process well established in many parts of the world. ${ }^{4}$ however these mitigation measures may lead to sub surface leakage overtime..$^{5}$ there by exposing the animals to unequivocal hypercapnia much satirical than the anthropogenic acidification of the oceans. ${ }^{6,7}$

Any changes in the ocean chemistry due to sub storage leakage or other anthropogenic sources can be easily prognosticated with high certainty. What is less certain at the present juncture is the consequence of such changes on the marine animals. We know very little about the animals that scarcely encounter such spatially restricted environment. Animals that are not regularly exposed to hypercapnic condition are highly sensitive. ${ }^{8}$ There are enough research evidences that suggest that the taxa dependent on calcium carbonate for building shells, skeletons and test are the most vulnerable to these changes. Most of the research on OA so far has been centered on the survival and the biology of the marine calcifying animals..$^{9,10}$

The present study here in attempts to assess the sensitive biomarker response to the sub lethal impacts of $\mathrm{pH}$ at 5 different levels on marine bivalve Donax cuneatus.

\section{Materials and methods}

\section{Animal collection and maintenance}

Donax cuneatus identified after Linnaeus, 1758 were collected from the intertidal region of the Gulf of Mannar at $09^{\circ} 15>06.43$ " N latitude and $079^{\circ} 06^{\prime} 33.71$ " E longitude. The collected animals were immediately transferred to the Pudhumadam field research laboratory with utmost care. The animals were washed with filtered sea water to remove the adhering epiphytes and acclimated to laboratory conditions with ambient requirements. The animals were fed twice a day with mixed phytoplankton culture.

\section{$\mathrm{CO}_{2}$ microcosm design}

Microcosm facility for the exposure was designed as per the descriptions of Widdicombe and Needham . ${ }^{11}$ and Dupont et al. ${ }^{12}$ The system consisted of two chambers viz. mixing chamber and an incubation chamber. The mixing chamber with 2 liters holding capacity was used to perturb the seawater where as the incubation chamber measuring 2 liters holding capacity was used to expose the animals to the acidified sea water. Six microcosms with six different $\mathrm{pH}$ regimes were used in the present study. The $\mathrm{pH}$ regimes selected 
for the study are 8.1 (control or unperturbed seawater), 7.5, 7.0, 6.5, 6.0 and 5.5. The lower limits 7.5 and 7.0 were selected based upon the seacarb output and approximated the modeled decrease in surface ocean $\mathrm{pH}$ by 2100 under the IPCC A2 SRES scenario of $\mathrm{CO}_{2}$ emissions. ${ }^{13}$ Whereas the $\mathrm{pH}$ ranges 6.5 - 5.5 mimicked the environment in the sub seabed $\mathrm{CO}_{2}$ leakage sites. ${ }^{11}$

\section{Seawater perturbation}

In order to mimic the natural process of ocean acidification, the seawater was manipulated by bubbling a mixture of pure $\mathrm{CO}_{2}$ and air until the desired $\mathrm{pH}$ was achieved. A pH stat system that ensured $100 \%$ gas flow and cut off ability when the $\mathrm{pH}$ went above or below the set value was used for the study. The seawater used for the study was pumped from Pudhumadam coast and stored in the over head tank which was then manipulated in the mixing chamber by gas bubbling. Manipulated seawater was then transferred to the incubation chamber.

\section{Medium term microcosm exposure}

Ten healthy animals were randomly allocated in each incubation chamber. The animals were maintained under 12:12 hours natural irradiation process. The animals were fed with mixed plankton culture throughout the experimental period. The $\mathrm{pH}$ in the chamber was maintained constant by a $\mathrm{pH}$ stat system and the dissolved oxygen levels in the chamber was monitored and maintained at ambient level. Water was siphoned twice a day to remove the organic load. Any changes in the behavior of the exposed animals were closely monitored

\section{$\mathrm{CO}_{2}$ microcosm environment analysis}

After allocating the animals any change in the seawater variables at constant $\mathrm{pH}$ was monitored at an equal interval throughout the experimental period. The $\mathrm{pH}$ of the water was monitored using Oakton $\mathrm{pH} 700$ bench top meter, where as Oakton waterproof DO 300 meter was used for measuring DO and Comark PDQ 400 high accuracy thermometer for temperature. $100 \mathrm{ml}$ of subsamples were collected in every 24 hours and subjected to TA analysis with the procedure adopted from River Watch Network . ${ }^{14}$

\section{Mortality rate}

Any sign of mortality was closely monitored throughout the experimental period. Mortality was confirmed by permanent opening of the shells. The deceased animals were immediately removed from the experimental chambers.

\section{Biomarker analysis}

Total tissue protein: Total protein concentrations were measured by Lowery et al. ${ }^{15}$ using BSA as reference standard material. Protein concentrations were expressed as $\mathrm{mg} / \mathrm{g}$ wet weight of tissue.

\section{Acetylcholine esterase activity}

The activity of AchE in the tissue of the exposed animals were analysed according to the method of Ellman et al. ${ }^{16}$ The reaction mixture contained Sodium phosphate buffer, DTNB, $10 \mathrm{mM}$ phosphate buffer and substrate ACTI. The increase in absorbance was read at 405 and $412 \mathrm{~nm}$ at 5 mins interval using Systronics double beam UV - Vis Spectrophotometer 2201 series. Molar extinction co- efficient (1.36 $\left.\times 10^{4} \mathrm{M}^{-1} \mathrm{~cm}^{-1}\right)$ was used to measure the AchE activity and the results were expressed in $\mu$ mols $\mathrm{min}^{-1} \mathrm{mg}^{-1}$ of total protein.

\section{Catalase activity}

CAT activity was measured as per the methods of Greenwald. ${ }^{17}$ by the decrease in absorbance at $240 \mathrm{~nm}$ due to $\mathrm{H}_{2} \mathrm{O}_{2}$ consumption. The difference in the absorbance per unit of time was measured as CAT activity $\left(\varepsilon=39.45 \mathrm{mM}^{-1} \mathrm{~cm}^{-1}\right)$. Results were expressed in mmol min ${ }^{1} \mathrm{mg}^{-1}$ of total protein concentration.

\section{Glutathione - s - transferase activity}

The GST assay was performed using a modified method based on Habig et al. ${ }^{18} 20 \mathrm{mM}$ CDNB was used as the substrate and $20 \mathrm{mM}$ GSH as the co-substrate. GST activity was estimated by measuring the formation rate of conjugated substrate (CDNB - GSH). Results were expressed in $\mu \mathrm{mol} \mathrm{min} \mathrm{mg}^{-1}$ of total protein.

\section{Lipid peroxidation}

Lipid Peroxidation was determined as described by Okhawa et al. ${ }^{19}$ Briefly, the reaction mixture consisted of $0.2 \mathrm{ml}$ of $8.1 \% \mathrm{SDS}, 1.5 \mathrm{ml}$ of $20 \%$ acetic acid $(\mathrm{pH} 3.5)$ and $1.5 \mathrm{ml}$ of $0.8 \%$ aqueous solution of TBA and $0.2 \mathrm{ml}$ of brain homogenate. The mixture was made up to $4 \mathrm{ml}$ with distilled water and heated at $950^{\circ} \mathrm{C}$ for $60 \mathrm{~min}$. After cooling with tap water, $5 \mathrm{ml}$ of $\mathrm{n}$-butanol and pyridine $(15: 1, \mathrm{v} / \mathrm{v})$ and $1 \mathrm{ml}$ of distilled water were added and centrifuged. The organic layer was separated out and its absorbance was measured at $532 \mathrm{~nm}$ in Systronics double beam UV- Vis Spectrophotometer 2201 series and MDA content was expressed as nmol/mg protein using molar extinction coefficient.

\section{Reduced glutathione activity}

RG was measured according to the method of Ellman. ${ }^{20}$ An equal quantity of tissue supernatant was mixed with $10 \%$ TCA and centrifuged to separate the proteins. To $0.1 \mathrm{ml}$ of this supernatant, $2 \mathrm{ml}$ of phosphate buffer ( $\mathrm{pH} 8.4$ ), $0.5 \mathrm{ml}$ of DTNB and $0.4 \mathrm{ml}$ of double distilled water were added. The mixture was vortexed and absorbance was read at $412 \mathrm{~nm}$ with in $15 \mathrm{~min}$. The concentration of reduced glutathione was expressed as $\mu \mathrm{mol} / \mathrm{g}$ tissue using molar extinction coefficient.

\section{Statistical analysis}

The data were expressed in mean $\pm \mathrm{SD}$. One way ANOVA using Stat plus 2009 was performed with $\mathrm{pH}$ as the factor and biomarkers as the dependent variables. $\mathrm{p}<0.05$ were assumed to be statistically significant. Regression analyses were also performed using Stat plus 2009.

\section{Results and discussion}

\section{$\mathrm{CO}_{2}$ microcosm environment analysis}

Climate change and OA are evil twins totally different from each other. Climate change involves green house effect that totally alters the climate but OA on the other hand alters the chemistry of seawater. OA which is caused by the uptake of $\mathrm{CO}_{2}$ is ruled by the $\mathrm{fCO}_{2}$ along with its uptake velocity which is in turn manipulated by water temperature, wind speed and other physico chemical parameters. ${ }^{21}$ In the present study mean changes in temperature, salinity, dissolved oxygen, total alkalinity and dissolved inorganic carbon were measured to rule out the impact of increasing carbon dioxide on these parameters. Unlike the intricate reactions involved in green house effect, the physico chemical changes in ocean acidification are simple and easy to monitor in an accurate manner for a given concentration of $\mathrm{CO}_{2}$ in seawater.

In the present study the changes in the physico chemical parameters in all the microcosm chambers were monitored four times a day at equal intervals throughout the experimental period. The $\mathrm{pH}$ was maintained constant and significant changes $(\mathrm{p}<0.05)$ was observed in the temperature, salinity, alkalinity and dissolved oxygen levels. 
The mean variations observed in the temperature, salinity, TA and DO are summarized in Figure 1a-1d. The control chamber exhibited the lowest temperature of $27.3 \pm 0.09$ where as the $\mathrm{pH} 6$ expressed the highest temperature of $28.0 \pm 0.05$. The lowest mean salinity of 33.2 \pm 0.5 was observed in control where as a highest salinity of $34.0 \pm 0.2$ was observed in $\mathrm{pH}$ 6. TA decreased with decreasing $\mathrm{pH}$. The $\mathrm{pH} 6$ expressed lowest alkalinity level of $2725.1 \pm 0.05 \mu \mathrm{mol} / \mathrm{kg}$ whereas control had a highest level of $2741.2 \pm 0.05 \mu \mathrm{mol} / \mathrm{kg}$. DO levels were constantly monitored and maintained at ambient levels. The oxygen level decreased with increasing $\mathrm{CO}_{2}$. Control chambers maintained an ambient dissolved oxygen levels of $5.6 \pm 0.1$ whereas the $\mathrm{pH} 6$ had the lowest level $4.9 \pm 0.1$.

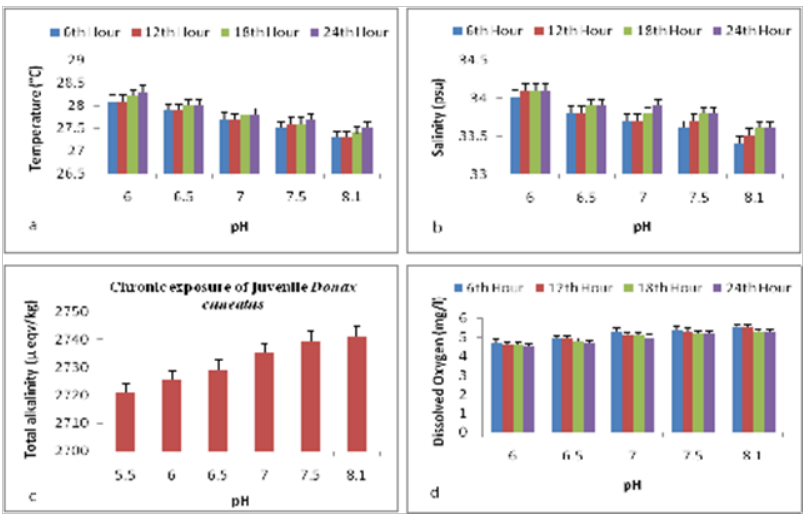

Figure I (a) Mean changes in the temperature of the microcosm chambers with respect to $\mathrm{pH}$ (b) Mean changes in the salinity of the microcosm chambers with respect to $\mathrm{pH}$ (c) Mean changes in the TA of the microcosm chambers with respect to $\mathrm{pH}$ (d) Mean changes in the DO levels of the microcosm chambers with respect to $\mathrm{pH}$.

For work in seawater, the $\mathrm{pH}(\mathrm{T})$ scale is the most commonly used scale and the recommended scale for monitoring activities ${ }^{22}$ An important advantage in the use of this scale is that problems associated with the uncertainties in the stability constants for hydro fluorides are avoided, and the preparation of appropriate buffer solutions is simplified. Hence $\mathrm{pH}(\mathrm{T})$ scale was used in the present study to measure, monitor and maintain $\mathrm{pH}$ in the microcosm chambers As per ICES report temperature plays a crucial role in the seasonal variation of $\mathrm{pH}$. In the present study temperature in the microcosm chambers were closely monitored.

Hauton et al. ${ }^{23}$ in his microcosm study on Gammarus locusta reported a change of $0.1-0.2^{\circ} \mathrm{C}$ in temperature in the two selected nominal $\mathrm{pH}$ (7.8 and 7.6) compared across the control. In the present study mean changes of $0.2-0.6^{\circ} \mathrm{C}$ was observed in the nominal $\mathrm{pH}$ when compared across control. Nevertheless these changes may increase in a mesocosm environment. Hauton also reported 0.2-0.4 psu changes in salinity in his microcosm chambers where as in the present study mean changes of 0.2-0.6 psu where observed in the nominal $\mathrm{pH}$ when compared across control. These changes may vary in the mesocosm environment owing to the extensive volume of water and other environmental factors. The dissolved oxygen levels remained optimum throughout the experimental period with mean changes of 0.1-0.5 mg/l compared to the control. Since the water in the chambers was completely changed for every twenty four hours the change in the dissolved oxygen was minimum and remained optimum.

\section{Mortality rate}

Significant rate of mortality was observed in $\mathrm{pH} 5.5,6.0$ and 6.5 after 15 days of exposure where as no mortality was observed in $\mathrm{pH}$ 7.0, 7.5 and control. The effect of Hypercapnia on the percentage mortality of the exposed animals is summarized in Figure 2. Apart from the sub lethal effects of induced hypercapnia, the survival rate of the exposed animals also depends upon the microcosm environment. The physicochemical parameters of the microcosm chambers varied significantly $(\mathrm{p}<0.05)$ with varying $\mathrm{pH}$ regimes thereby indicating an inter relationship between $\mathrm{pCO}_{2}$ and seawater variables.

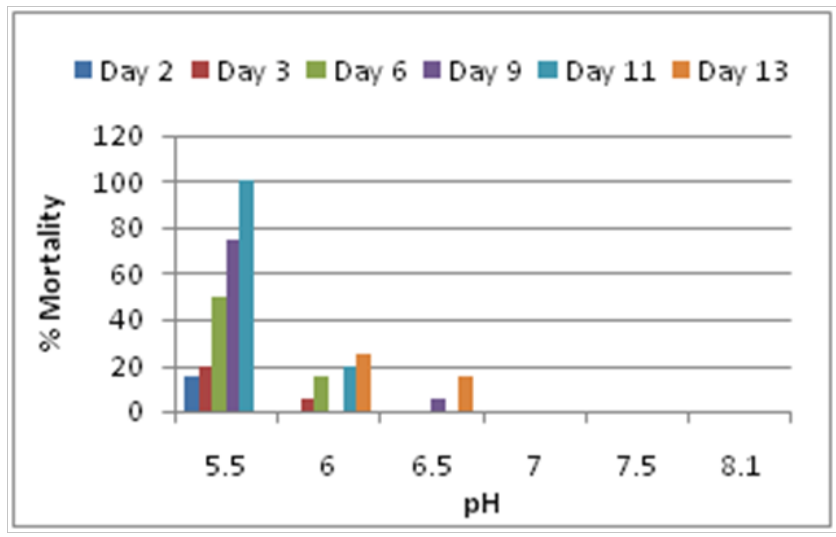

Figure $\mathbf{2} \%$ mortality of Donax cuneatus exposed to the nominal $\mathrm{pH}$ regimes.

\section{Biomarker analysis}

Apart from physicochemical parameters most of the study to date focuses on the changes in calcification rate rather than on the physiological processes that induces these changes. ${ }^{24}$ There are many physiological processes that is affected by ocean acidification which leads to metabolic suppression, oxidative stress, apoptosis and symbiont loss. ${ }^{25-27}$ By measuring these physiological processes, any discrepancies observed in rate of calcification with respect to ocean acidification can be unraveled. Hence in the present study ocean acidification induced physiological changes observed in marine bivalve Donax cuneatus at the phenotype level using sensitive biomarkers.

Among the biological tools recommended for marine pollution monitoring, biomarkers have been successfully incorporated in the assessment of the quality of the coastal environment. ${ }^{28,29}$ Biomarkers provide early warnings on the sublethal physiological impacts.$^{30}$ Aquatic organisms, especially marine bivalves, exhibit a variety of changes in enzymatic antioxidant defenses after exposure to pollutants with oxidative potential ${ }^{31}$ In the present study we have estimated the activity of AChE an important enzyme that hydrolyzes the neurotransmitter acetylcholine, the antioxidant enzyme CAT and LPO indicators of oxidative stress, the activity of RG and GST, an enzyme of the phase II of biotransformation that catalyzes the conjugation of RG to cellular components damaged by reactive oxygen species attack, leading to their detoxication process, to evaluate their utility as biological tools for ocean acidification monitoring in the Gulf of Mannar.

Total tissue protein: Measurement of the above said biomarkers are greatly dependent on the levels of total tissue protein levels. The total protein concentration in the tissues of the exposed animals decreased gradually with decreasing $\mathrm{pH}$. The animals exposed to the lowest $\mathrm{pH}$ of 6 expressed a value of $0.5891 \mathrm{~g}$ of protein/g tissue compared to the control which exhibited the value of $2.4174 \mathrm{~g}$ of protein/g tissue (Figure 3a). Significant changes $(p<0.05)$ were observed between the animals exposed to the control seawater and the animals exposed to the nominal $\mathrm{pH}$ regimes. 


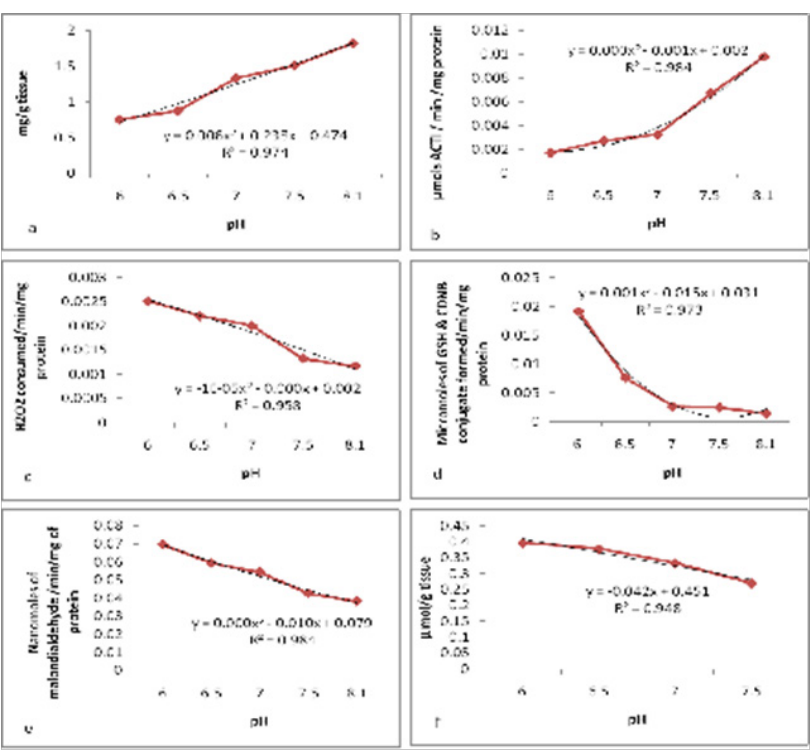

Figure 3 (a) Impacts of Hypercapnia on total protein concentration. (b) Impacts of hypercapnia on AchE activity. (c) Impacts of hypercapnia on CAT activity. (d) Impacts of hypercapnia on GST activity. (e) Impacts of hypercapnia on lipid peroxidation ( $f$ ) Impacts of hypercapnia on RG activity.

Acetylcholine esterase activity: In the present study the animals exposed to all nominal $\mathrm{pHs}$ displayed an increase in activity of all antioxidant enzymes except AchE, which displayed decrease in activity. As per Podolska \& Napierska. ${ }^{32}$ AchE tends to increase in animals existing in cleaner environment hence the decrease in AchE levels in the present study may be attributed to OA induced oxidative stress. The AchE enzyme activity decreased with decreasing $\mathrm{pH}$ levels. The activity decreased from $0.0024 \mu$ mols min- $1 \mathrm{mg}-1$ of total protein to $0.0001 \mu \mathrm{mols} \mathrm{min}^{-1} \mathrm{mg}^{-1}$ of total protein in $\mathrm{pH} 6$ after 15 days of exposure (Figure $3 b$ ).

Catalase activity: An increase in the levels of CAT and RG has been reported in sea anemones exposed to copper chloride which was further intensified at low. ${ }^{33-35}$ Similarly in the present study increase in CAT, RG and GST levels at decreased $\mathrm{pH}$ were observed which might be further intensified by environmental toxicants. Stress induced increase in the enzyme activity was observed by CAT assay. The enzyme activity increased from $0.010 \mathrm{~min}^{-1} \mathrm{mg}^{-1}$ protein to 0.038 $\mathrm{min}^{-1} \mathrm{mg}^{-1}$ protein in the lowest $\mathrm{pH}$ of 6 after 15 days of exposure. A significant increase $(p<0.05)$ in the enzyme activity was observed (Figure 3c). Significant differences were observed between the control and hypercapnia treated animals

Glutathione - s - transferase activity: The GST enzyme activity increased with decreasing $\mathrm{pH}$. Control exhibited an activity of 0.0025

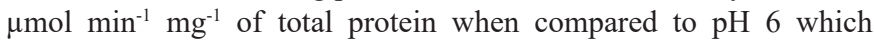
expressed an activity of $0.0264 \mu \mathrm{mol} \mathrm{min} \mathrm{mg}^{-1} \mathrm{mg}^{-1}$ of total protein (Figure 3d).

Lipid peroxidation: Pimentel et al. ${ }^{36}$ reported increased levels of lipid peroxidation (based on MDA levels) under high temperature and $\mathrm{pCO}_{2}$. Correspondingly lipid peroxidation (also based on MDA levels) increased at low $\mathrm{pH}$ and high $\mathrm{pCO}_{2}$ in the present study. The level of MDA increased from $0.251 \mathrm{nmol} / \mathrm{mg}$ (Control) to $0.858 \mathrm{nmol} /$ $\mathrm{mg}$ in $\mathrm{pH} 6$ after 15 days of exposure. The enzyme activity increased significantly $(\mathrm{p}><0.05)$ with decreasing $\mathrm{pH}$ (Figure $3 \mathrm{e}$ ).

Reduced glutathione activity: The level of RG gradually increased with decreasing $\mathrm{pH}$ after 15 days of exposure. Significant changes $(p<0.05)$ were observed in the enzyme activity due to induced hypercapnia. The RG levels increased from $0.20 \mu \mathrm{mol} / \mathrm{g}$ (Control) to $0.36 \mu \mathrm{mol} / \mathrm{g}$ in the $\mathrm{pH} 6$ after fifteen days of exposure (Figure 3f).

Cossu et al ${ }^{37}$ reports that under stress the antioxidant system of the animals may either be activated or inhibited. The activation and inhibition are two contradictory responses that are dependent on the duration and intensity of the stressors as well as on the sensitivity of the animals exposed. Activation indicates the adaptation of the animals to the stressor where as inhibition indicates later stage of oxidative stresses. ${ }^{38}$

\section{Statistical analysis}

Two ways ANOVA revealed that all the seawater variables showed highly significant change across $\mathrm{pH}$ and time except salinity which exhibited marginally significant change across time (Table 1). The one way ANOVA for biomarkers had a significant result (Table 2).

The R2 value for each biomarker along with their trends has been represented in Table 3. Regression analysis of all the biomarker enzymes in the present study displayed value nearer to one there by having a perfect fit to their respective trend lines.

Table I Two Way ANOVA on the effects of hypercapnia on seawater variables across $\mathrm{pH}$ and time

\begin{tabular}{llllll}
\hline S. No & Parameters & \multicolumn{4}{l}{ Variation Across pH } \\
& & F & P & F & P \\
\hline I & Temperature & 327 & 0.000 & 36.66 & 0.000 \\
2 & Salinity & 204.5 & 0.000 & 18.7 & 0.000 \\
3 & DO & 181.1 & 0.000 & 25 & 0.000 \\
4 & TA & 356.6 & 0.000 & - & - \\
\hline
\end{tabular}

Table 2 One way ANOVA on the effects of hypercapnia on biomarkers

\begin{tabular}{lllllll}
\hline $\begin{array}{l}\text { Source of } \\
\text { Variation }\end{array}$ & SS & df & MS & F & P-value & F crit \\
\hline Between Groups & 0.368255 & 4 & 0.092064 & 70.7414 & I.63E-II & 2.86608 I \\
Within Groups & 0.026028 & 20 & 0.001301 & & & \\
Total & 0.394283 & 24 & & & & \\
\hline
\end{tabular}

Table 3 Regression analysis of the effects of hypercapnia on biomarkers and protein

\begin{tabular}{llll}
\hline S. No & Biomarker & Regression $\mathbf{R}^{2}$ & Trend \\
\hline I & Protein & 0.9746 & Logarithmic \\
2 & Acetylcholine Esterase & 0.9844 & Polynomial \\
3 & Catalase & 0.9588 & Polynomial \\
4 & Lipid Peroxidase & 0.9849 & Linear \\
5 & Glutathione S Transferase & 0.973 & Logarithmic \\
6 & Reduced Gltathione & 0.948 & Linear \\
\hline
\end{tabular}

\section{Conclusion}

Extensive variation has been observed so far in the response of inter specific species towards OA. In order to discriminate and understand these responses and their impacts there is a strong need to imply a sensible and sensitive toxicology testing to monitor the impacts of ocean acidification. Such stress response evaluation is valuable to monitor OA impacts in the provinces vulnerable to industrial contaminant, since proficient testing of impacts induced by toxicants that are acid dependent can be monitored effectively. Biomarkers used in the present study has proven to be one such stress monitoring tool used in effective monitoring of $\mathrm{OA}$ as well as environmental contaminants. From the present study it is concluded that juvenile 
marine bivalves Donax cuneatus responds negatively with respect to ocean acidification. Donax cuneatus are highly sensitive to lower $\mathrm{pH}$ and endure extreme oxidative stress by OA alone as evident from the control group. However these impacts can be further intensified by other toxicants prevalent in the environment hence further intensive and cumulative studies are required to examine the combined impacts of ocean acidification and environmental toxicants.

\section{Acknowledgements}

The first author is thankful to the University Grants Commission for providing Basic Science Research fellowship and DST PURSE for the consumable support for completing the study.

\section{Conflicts of interest}

None.

\section{References}

1. Orr JC, Fabry VJ, Aumont O, Bopp L, Doney SC, et al. Anthropogenic ocean acidification over the twenty-first century and its impact on calcifying organisms. Nature. 2005;437(7059):681-686.

2. IPCC. Contribution of Working Group I to the Fourth Assessment Report of the IPCC. In: S Solomon \& D Qin et al. (Eds.), Climate Change 2007: The Physical Science Basis. Cambridge University Press, Cambridge, UK,. 2007a ;pp.996.

3. IPCC. Contribution of Working Groups I, II and III to the Fourth Assessment Report of the Intergovernmental Panel on Climate Change. In: Pachauri RK \& Reisinger A (Eds.), Climate Change 2007: Synthesis Report. IPCC, Geneva, Switzerland. 2007b ;pp.104.

4. Holloway S. Underground sequestration of carbon dioxide-a viable greenhouse gas mitigation option. Energy. 2005;30(11-12):2318-2333.

5. Hawkins DG. No exit: thinking about leakage from geologic carbon storage sites. Energy. 2004;29(9-10):1571-1578.

6. Seibel BA, Walsh PJ. Potential impacts of CO2 injection on deep-sea biota. Science. 2001;294(5541):319-320.

7. Carman KR, Thistle D, Fleeger JW, et al. Influence of introduced CO2 on deep-sea metazoan meiofauna. J Oceanogr. 2004;60(4):767-772.

8. Spicer JI, Raffo A, Widdicombe S Influence of $\mathrm{CO} 2$ - related seawater acidification on extracellular acid-base balance in the velvet swimming crab Necora puber. Mar Biol (Berl). 2007;151(3):1117-1125.

9. Kurihara H, Shirayama Y Effects of increased atmospheric CO2 on sea urchin early development. Mar Ecol Prog Ser. 2004;274:161-169.

10. Thistle D, Carman KR, Sedlacek L, PG, Fleeger JW, et al. Deep-ocean, sediment-dwelling animals are sensitive to sequestered carbon dioxide. Mar Ecol Prog Ser. 2004;289:1-4.

11. Widdicombe S, Needham HR Impact of $\mathrm{CO} 2-$ induced seawater acidification on the burrowing activity of Nereis virens and sediment nutrient flux. Mar Ecol Prog Ser. 2007;341:111-122.

12. Dupont S, Havenhand J, Thorndyke W, et al. Near-future level of $\mathrm{CO} 2-$ driven ocean acidification radically affects larval survival and development in the brittlestar Ophiothrix fragilis. Mar Ecol Prog Ser. 2008;373: 285-294.

13. Caldeira K, Wickett ME Ocean model predictions of chemistry changes from carbon dioxide emissions to the atmosphere and ocean. $J$ Geophys Res. 2005;110(C9).

14. River Watch Network Total alkalinity and $p H$ field and laboratory procedures (based on University of Massachusetts Acid Rain Monitoring Project). 1992
15. Lowry OH, Rosebrough NJ, Farr AL, Protein measurement with the Folin phenol reagent. J Biol Chem. 1951;193:265-275.

16. Ellman GL, Lourtney DK, Andres V, et al.A new and rapid colorimetric determination of acetylcholinesterase activity. Biochem Pharmacol. $1961 ; 7: 88-95$.

17. Greenwald RA Handbook of Methods for Oxygen Radical Research. Boca Raton, CRC Press, Florida, USA. 1985

18. Habig WH, Pabst MJ, Jakoby WB Glutathione Stransferases First enzymatic step in mercapturic acid formation. $J$ Biol Chem. 1974;249(22):7130-7139.

19. Ohkawa $\mathrm{H}$, Ohishi N, Yagi K Assay for lipid peroxides in animal tissues by thiobarbituric acid reaction. Anal Biochem. 1979;95(2): 351-358.

20. Ellman GL ( Tissue sulphydryl groups. Arch Biochem Biophys. 1979;82(1):70-77.

21. Hydes DJ, McGovern E, Walsham P Chemical aspects of ocean acidification monitoring in the ICES marine area. ICES Cooperative Research Report p. 1979;78.

22. DOE Handbook of methods for the analysis of the various parameters of the carbon dioxide system in sea water. In: $A G$ Dickson \& $C$ Goyet (Eds.), ORNL/CDIAC-74. 1994

23. Hauton C, Tyrrell T, Williams $\mathrm{J}$ The subtle effects of sea water acidification on the amphipod Gammarus locusta. Biogeosciences. 1994;6:1479-1489.

24. Doney SC, Fabry VJ, Feely RA, et al. Ocean acidification: the other CO2 problem. Апnи Rev Mar Sci 1. 2009;169-192.

25. Anthony KRN, Kline DI, Diaz-Pulido G, et al. Hoegh-Guldberg $\mathrm{O}$ Ocean acidification causes bleaching and productivity loss in coral reef builders. Proceedings of the National Academy of Science. 2008;105(45):17442-17446

26. Munday PL, Leis JM, Lough JM, et al. Climate change and coral reef connectivity. Coral Reefs. 2008;28(2):379-395.

27. Pörtner HO Ecosystem effects of ocean acidification in times of ocean warming: a physiologist's view. Mar Ecol Prog Ser. 2008;373:203-217.

28. Adams SM, Greeley MS, Ryon MG Evaluating effects of contaminants on fish health at multiple levels of biological organisation: extrapolating from lower to higher levels. Hum Ecol Risk Assess. 2000;6(1): 15-27.

29. Narbonne JF, Aarab N, Clérandeau C, et al. Scale of classification based on biochemical markers in mussels: application to pollution monitoring in Mediterranean coasts and temporal trends. Biomarkers. 2005;10(1):58-71.

30. Damiens G, Gnassia-Barelli M, Loquès F, et al. Integrated biomarker response index as a useful tool for environmental assessment evaluated using transplanted mussels. Chemosphere. 2007;66(3):574-583.

31. Lam PKS Use of biomarkers in environmental monitoring. Ocean \& Coast Manage. 2009;52(7):348-354.

32. Podolska M, Napierska D Acetylcholinesterase activity in hosts (herring Clupeaharengus) and parasites (Anisakis simplex larvae) from the southern Baltic. ICES journal of Marine Science. 2006;63(1):161168

33. Brock JR, Bielmyer GK Metal accumulation and sublethal effects in the sea anemone, Aiptasia pallida, after waterborne exposure to metal mixtures. Comp Biochem Physiol C Toxicol Pharmacol. 2013;158(3):150-158

34. Patel PP, Bielmyer-Fraser GK The influence of salinity and copper exposure on copper accumulation and physiological impairment in the sea anemone, Exaiptasia pallida. Comp Biochem Physiol C Toxicol Pharmacol. 2015;68:39-47. 
35. Siddiqui S, Bielmyer-Fraser GK Responses of sea anemone, Exaiptasia pallida, to ocean acidification conditions and copper exposure. Aquat Toxicol. 2015; 167:228-239.

36. Yebra-Pimentel I, Fernández-González R, Martínez-Carballo E,et al. A critical review about the health risk assessment of PAHs and their metabolites in foods. Crit Rev Food Sci Nutr. 2015;55(10):1383-1405.
37. Cossu C, Doyotte A, Babut M, et al.Antioxidant biomarkers in freshwater bivalves, Unio tumidus, in response to different contamination profiles of aquatic sediments. Ecotoxicol Environ Saf. 2000;45(2):106-121.

38. Pereira JA, Oliveira I, Sousa A, et al. ( Walnut (Juglans regia L.) leaves: phenolic compounds, antimicrobial activity and antioxidant potential of different cultivars. Food Chem Toxicol. 2000;45(11):2287-2295. 